\title{
KAJIAN SKALA USAHA PENDEDERAN I IKAN PATIN (Pangasius hypopthalmus) PADA AKUARIUM DI KECAMATAN PARUNG - KEMANG - CISEENG TERHADAP PENDAPATAN SETARA UMR (Upah Minimum Regional) KABUPATEN BOGOR
}

\author{
Oleh \\ Paidi, Ganjar Wiryati \\ Dosen Jurusan Penyuluhan Perikanan Sekolah Tinggi Perikanan
}

\begin{abstract}
ABSTRAK
Permintaan ikan patin konsumsi menunjukan peningkatan dari waktu ke waktu, hal ini membawa dampak peluang usaha pendederan ikan patin kearah yang positif. Penelitian ini bertujuan untuk memberkikan injformasi pendapatan yang dapat dicapai setara dengan Upah Minimum Regional (UMR) Bogor, dari kegliatan usaha pendederan ikan patin pada aquarium di kecamatan ciseeng, kemang dan parung. Sehingga dapat membantu mengambil suatu keputusan bagi seorang calon pengusaha pendeederan ikan patin.

Prosedur penelitian dimulai pengadaan sarana produksi, persiapan aquarium, penebaran dan pemeliharaan benih ikan patin, serta pemasaran benih ikan patin. Penelitian dilakukan dengan menggunakan Rancangan Acak Lengkap (RAL) dengan tiga lokasi dan masing-masing dilakukan tiga ulangan, jumlah 30, 40 dan 60.

Data yang dikumpulkan dari hasil pengamatan adalah biaya tetap, biaya variable, total pendapatan dan Upah Minimum Regional Bogor. Metoda analisis financial yang digunakan adalah laba/rugi, R/C, BEP, Payback Period dan ROI.
\end{abstract}

Kata Kunci : Jumlah Aquarium, Analisa Financial, Pendapatan, Upah regional.

\section{PENDAHULUAN}

\section{Latar Belakang}

Ikan Patin (Pangasius sp) telah lama dibudidayakan di Indonesia. Daerah penyebarannya meliputi Pulau Jawa, Sumatera, Kalimantan, Bali, Sulawesi, dan lainnya. Ikan Patin mempunyai rasa yang enak, dagingnya tebal, mudah dibudidayakan dan bernilai ekonomis.

Budidaya ikan patin menunjukan kecenderungan meningkat disebabkan peningkatan permintaan pada tingkat ukuran konsumsi, hal tersebut berimplikasi pada peningkatan permintaan benih baik dari kuantitas maupun kualitas. Produksi benih patin daerah Bogor tidak hanya untuk memenuhi kebutuhan lokal namun sebagian dikirim keluar pulau, seperti Sumatera, Bali, Nusa Tenggara dan Kalimantan.

Untuk memproduksi benih patin ukuran $3 / 4$ inchi terdapat segmen kegiatan tersendiri yaitu usaha pendederan. Kegiatan tersebut dilakukan oleh para pembudidaya pada wadah berupa hatchery. Kegiatan biasanya dilakukan pada unit-unit pembenihan rakyat (UPR) skala kelompok kecil atau 
keluarga, baik sebagai usaha pokok atau hanya sebagai usaha sampingan.

Melihat kenyataan bahwa kegiatan pendederan ikan patin menjadi salah satu jenis usaha atau kegiatan usaha tersendiri maka diperlukan kajian yang lebih terinci dan detail yang berkaitan dengan parameter-parameter analisis ekonomi pada kegiatan usaha tersebut.

Salah satu tolak ukur pendapatan masyarakat yang layak untuk memenuhi kebutuhan standar minimal adalah tingkat upah minimum. Kegiatan pendederan ikan patin sebagai salah satu kegiatan ekonomi perlu mendapatkan informasi kajian atau analisis yang berkaitan besaran skala usaha yang disertakan dengan Upah Minimum Regional (UMR). Kajian analisis ekonomi yang memiliki validitas yang baik akan membantu ketepatan dalam memprediksi input dan output dalam usaha pendederan ikan patin.

\section{Rumusan Masalah}

Sumber tenaga manusia merupakan faktor produksi yang tidak dapat disimpan atau ditunda penggunaannya seperti faktor produksi lain yang berupa bahan atau barang, karena biaya akan terus dikeluarkan seiring dengan berjalanya waktu.

Dengan metode analisis data yang diambil dari data deskriftif hasil kajian yang didasarkan pada variable-variable input dan output maka akan ditemukan titik besaran skala usaha yang dapat memberikan penghasilan nilai nominal setara dengan Upah Minimum Regional (UMR).

\section{Tujuan penelitian}

Memberikan informasi tentang besarnya skala usaha pendederan ikan patin yang memberikan nominal output setara dengan Upah Minimum Regional (UMR), sehingga timbul motifasi usaha bagi calon pengusaha pendederan ikan patin.

\section{Kontribusi Penelitian}

Sebagai bahan acuan bagi calon investor untuk menentukan besaran skala usaha dan jumlah tenaga kerja yang diperlukan.

\section{KERANGKA PEMIKIRAN}

\section{Kerangka Pemikiran}

Alur pikir dapat dilihat pada gambar dibawah ini.

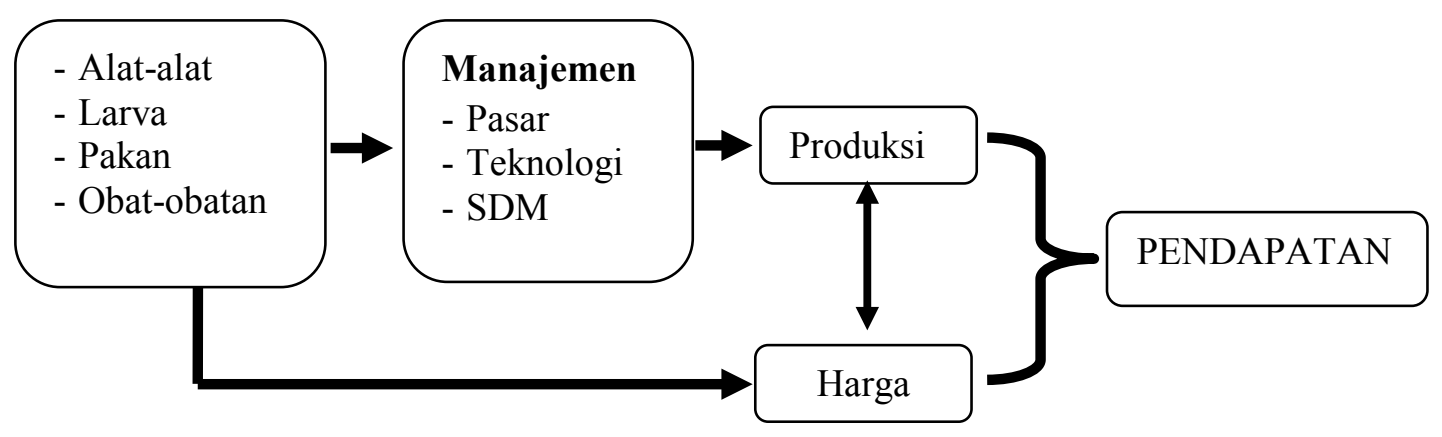

Gambar 1. Alur Pikir 
Faktor penentu dari hasil akhir atau output bersih yang kemudian dinyatakan dalam bentuk nominal berupa pendapatan adalah besaran jumlah produksi dikalikan harga satuan.

\section{Varibel Penelitian}

a. Faktor internal perusahaan

1) Harga

2) Jumlah Produksi

\section{Hipotesis}

Dengan menganalisis variablevariable input dan output pada usaha pendederan ikan patin akan dapat memberikan informasi besaran skala usaha yang memberikan pendapatan serta dengan Upah Minimum Regional (UMR).

Tabel 1. Rincian bahan penelitian

\begin{tabular}{|l|l|}
\hline \multicolumn{1}{|c|}{ No } & \multicolumn{1}{c|}{ Nama Bahan } \\
\hline 1 & Larva Ikan patin \\
\hline 2 & Pakan (cacing tubifex spp) \\
\hline 3 & Obat - obatan \\
\hline 4 & Alat tulis \\
\hline
\end{tabular}

Tabel 2. Peralatan untuk penelitian

\begin{tabular}{|l|l|}
\hline No & Nama Bahan \\
\hline 1 & Akuarium \\
\hline 2 & Lambit \\
\hline 3 & Timbangan \\
\hline 4 & Saringan grading \\
\hline 5 & Hapa \\
\hline
\end{tabular}

\section{Prosedur Penelitian}

Tahapan prosedur penelitian di mulai dari pengadaan saprodi. Tiap bacth/ ulangan pada kelompok penelitian dilakukan kegiatan meliputi : pengolahan persiapan media,

\section{PELAKSANA KEGIATAN}

\section{Tempat dan Waktu Penelitian}

Penelitian dilakukan di unit-unit usaha pembenihan rakyat (UPR) yang berlokasi di Kecamatan Parung, Kecamatan Kemang dan Kecamatan Ciseeng, Kabupaten Bogor. Kegiatan ini dilakukan dari bulan Juni sampai dengan bulan Agustus 2012.

\section{Bahan dan Alat Penelitian}

Bahan dan alat untuk pelaksanaan penelitian terinci pada Tabel $\mathbf{1}$ dan $\mathbf{2}$ sebagai berikut. 


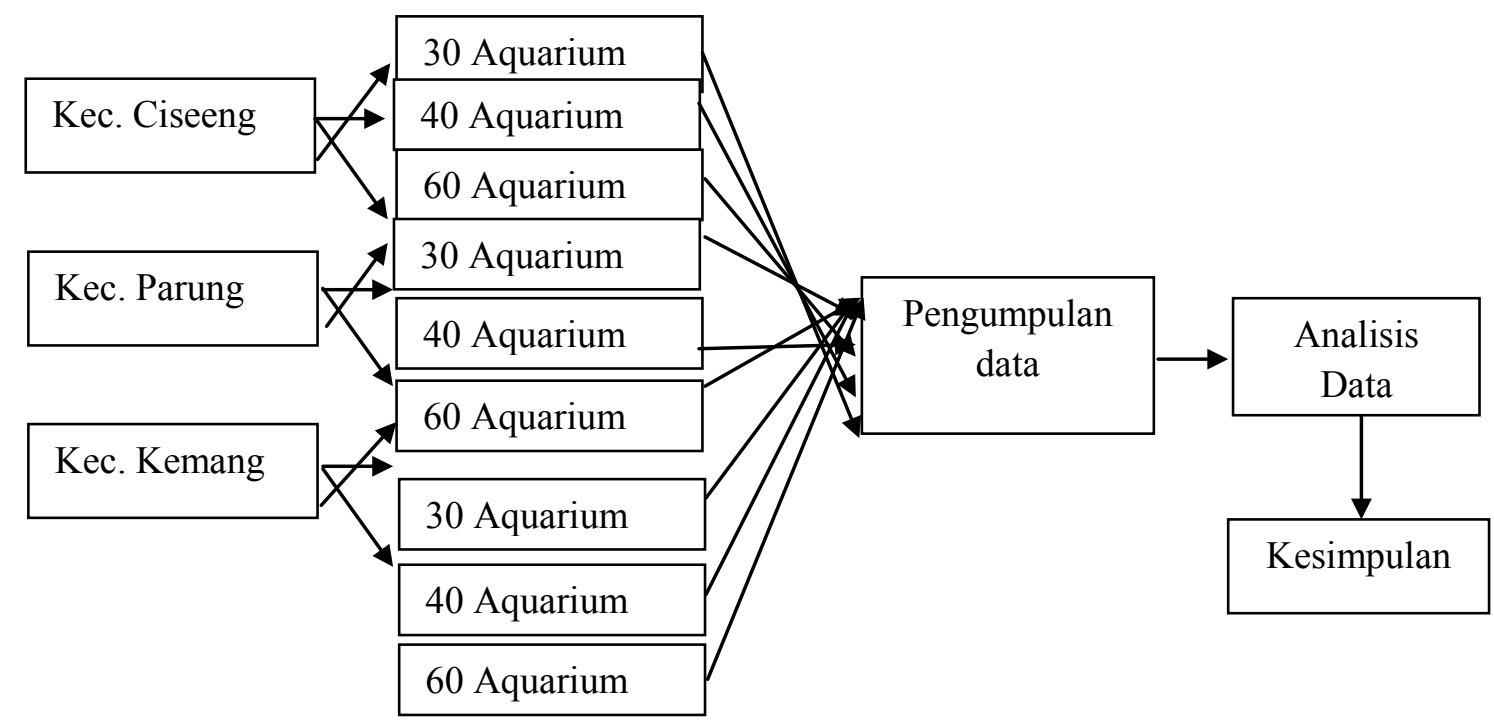

Gambar 2. Bagan alur dan rancangan penelitian

\section{Pengumpulan Data}

Rincian data data yang di

kumpulkan dari hasil pengamatan adalah :

Total input yang meliputi :
a. Biaya Tetap
b. Biaya Variabel
c. Biaya Tenaga Kerja

Analisis Yang di Lakukan Adalah :
a. Laba/ Rugi
b. R/C Ratio
c. BEP Produk
d. BEP Harga
e. Pay Back Period
f. ROI

Tabel 3. Rekapitulasi Rata-Rata Output

\begin{tabular}{|c|c|c|c|c|}
\hline NO & NAMA & OUTPUT & RATA-RATA & $\begin{array}{c}\text { LABA } \\
\text { RATA-RATA }\end{array}$ \\
\hline \multirow{3}{*}{1} & Gaguk & 8.115 .000 & \multirow{3}{*}{8.005 .000} & \multirow{3}{*}{1.226 .000} \\
\hline & Ayung & 8.100 .000 & & \\
\hline & Eka & 7.800 .000 & & \\
\hline \multirow{3}{*}{2} & Oman & 10.716 .666 & \multirow{3}{*}{11.399 .999} & \multirow{3}{*}{3.143 .999} \\
\hline & Enji & 11.983 .333 & & \\
\hline & Arif & 11.500 .000 & & \\
\hline \multirow{3}{*}{3} & Fran & 17.876 .666 & \multirow{3}{*}{18.025 .555} & \multirow{3}{*}{6.221 .555} \\
\hline & Jono & 18.466 .666 & & \\
\hline & Melati & 17.733 .333 & & \\
\hline
\end{tabular}




\section{HASIL DAN PEMBAHASAN}

Tabel 4. Hasil Analisa Finansial Usaha

\begin{tabular}{|c|c|c|c|c|c|c|c|c|c|c|}
\hline \multirow{2}{*}{ No } & \multirow{2}{*}{$\begin{array}{c}\sum \\
\text { Aquarium }\end{array}$} & \multicolumn{2}{|c|}{ Total Cost } & \multirow{2}{*}{ TR } & $\begin{array}{c}\text { Untung } \\
\text { Rugi }\end{array}$ & R/C & $\begin{array}{c}\text { BEP } \\
\text { (Rp) }\end{array}$ & $\begin{array}{c}\text { BEP } \\
\text { (Unit) }\end{array}$ & $\begin{array}{c}\text { Payback } \\
\text { Periode }\end{array}$ & ROI \\
\hline 1. & 30 & 4.505 .000 & 2.274 .000 & 8.005 .000 & 1.226 .000 & 1,18 & 50 & 112.983 & 5,5 & 0,18 \\
\hline 2. & 40 & 5.877 .900 & 2.474 .000 & 11.399 .999 & 3.143 .999 & 1,3 & 44 & 139.199 & 2,7 & 0,38 \\
\hline 3. & 60 & 8.830 .000 & 2.974 .000 & 18.025 .555 & 6.221 .555 & 1,5 & 39 & 196.733 & 1,9 & 0,5 \\
\hline
\end{tabular}

Untuk mengetahui keberhasilan usaha dengan melihat kajian finansial dilakukan secara kualitatif dan kuantitatif (dapat dilihat pada Tabel 3). Analisis kuantitatif dalam penelitian ini meliputi analisis pendapatan, $\mathrm{R} / \mathrm{C}$ rasio, BEP Unit, BEP Rupiah, Payback period dan ROI. Total penerimaan kegiatan usaha pendederan berbagai skala di kecamatan Parung, Kemang dan Ciseeng dengan masing-masing skala usaha 30 aquarium sebesar Rp. 8.005.000,- skala 40 aquarium Rp.11.399.999,-skala 60 aquarium Rp. 18.025.555,- per siklus produksi. Sedangkan biaya tunai dan biaya diperhitungkan yang harus dikeluarkan skala 30 aquarium sebesar Rp. 6.779.000,- skala 40 aquarium sebesar Rp. 8.351900,- skala 60 aquarium Rp. 11.804000,-per siklus produksi. Sehingga diperoleh $\mathrm{R} / \mathrm{C}$ rasio atas biaya totali sebesar 1,18 persiklus skala 30 aquarium, $\mathrm{R} / \mathrm{C}$ rasio 1,3 persiklus skala 40 aquarium, $\mathrm{R} / \mathrm{C}$ rasio 1,5 per siklus skala 60 aquarium.

Dilihat dari nilai $\mathrm{R} / \mathrm{C}$ rasio yang diperoleh tersebut, dapat dilihat bahwa kegiatan usaha pendederan I ikan patin efisien untuk dilakukan.

Dari hasil perhitungan yang dilakukan berdasarkan masing-masing skala usaha di tunjukkan bahwa nilai BEP rupiah mulai dari Rp. 50,-, Rp.44,Rp. 39 hal ini berarti bahwa titik impas rupiah berada di harga jual unit Rp. 50 rupiah untuk skala 30 aquarium,- $\mathrm{Rp}$. 44,- untuk skala 40 aquarium, dan Rp. 39,- skala 60 aquarium. Ada pun jumlah unit sebagai titik impas berada pada angka 112.983 unit skala 30 aquarium, 139.199 unit skala 40 unit, 196.733 skala 60 unit. Ini membantu untuk memberikan tampilan yang dinamis dari hubungan antara penjualan, biaya, dan keuntungan

Dari perhitungan Rugi/laba menunjukkan bahwa rata-rata laba yang di peroleh setiap skala usaha pada skala usaha dengan jumlah aquarium $30 \mathrm{bh}$ di peroleh laba rata-rata sebesar Rp. 1.226.000,- jumlah aquarium 40 bh laba rata-rata sebesar Rp. 3.143.000,- dan pada jumlah aquarium 60 bh laba ratarata sebesar Rp. 6.221.555,- dari laba rata-rata berbagai skala usaha menunjukkan bahwa bila di bandingkan dengan Upah minimum Kota/Kabupaten masih berada di atas rata-rata upah minimum kota/kabupaten yang ada di wilayah Jawa Barat.

Payback period (PP) adalah jangka waktu pengembalian modal investasi yang akan dibayar melalui keuntungan yang diperoleh Semakin cepat pengembalian semakin cepat usahanya. Bila di lihat hasil perhitungan PP maka yang paling cepat mengembalikan modal investasinay yaitu yang memiliki skala usaha yang paling tinggi yaitu skala 60 aquarium dengan nilai PP 1,9 , untuk skala 40 
aquarium nilai PP 2,7 dan untuk skala 30 aquarium nilai PP 5,5. Sehingga dengan demikian waktu pengembalian investasi pada masing-masing skala usaha dapat dilihat.

UMK (Upah Minimum

Kota/Kabupaten) di keluarkan perusahaan sesuai masa kerja setiap satu bulan sekali. Besaran UMK Bogor adalah Rp. 1.174.000. Sehingga nilai ini dapat dicapai dengan sekala usaha minimum 30 aquarium.

\section{KESIMPULAN DAN SARAN}

Dari data hasil kajian analisa finansial dapat disimpulkan bahwa kegiatan usaha pendederan ikan patin dikecamatan ci seeng, kemang dan kecamatan parung hendaknya dilakukan minimal dengan skala 30 aquarium, dengan ukuran aquarium $1 \mathrm{~m} \mathrm{X} \mathrm{0,5} \mathrm{m} \mathrm{X}$ $0,5 \mathrm{~m}$.

\section{DAFTAR PUSTAKA}

Hanafiah dan Saefudin. 2006. Tataniaga Hasil Perikanan. Universitas Indonesia. Jakarta

Nasrudin. W dan Nuraini Ida. 2006. Manajemen Agribisnis. Universitas Terbuka.

Rahadi, F., Nazaruddin, dan Regina Kristiawati. 2005. Agribisnis Perikanan. Penebar Swadaya. Jakarta

http://wordpress.com/2009/01/12/inform asi-upah-minimum-regional-umr/. 